\title{
Effectiveness of Acuyoga (Accupresure and Yoga) Antenatal and Pregnancy Massage Against Intensity of back pain and sleep disturbance in Third Trimester Pregnant Woman in dr.Aisyatul Mukminah Sp.OG (K)'s Practice in Tulungagung
}

\author{
Putri Eka Sejati $^{1}$, Indasah $^{2}$, Koesnadi $^{3}$ \\ Graduate Program STIKes Surya Mitra Husada Kediri \\ putridanialin@gmail.com
}

\begin{abstract}
Various physiological changes occur in the mother's body during pregnancy which can affect the occurrence of low back pain and sleep disturbance during pregnancy trimester 3. One of the non-pharmacological therapy to reduce the incidence is with antenatal acuyoga and pregnancy massage. This is because acuyoga and massage will produce more endorphins that serve to provide peace, to overcome stress during pregnancy. The purpose of research to analyze the effectiveness of antenatal acuyoga and pregnancy massage to the intensity of low back pain and sleep disturbance of pregnant women trimester III The purpose of research to analyze the effectiveness of antenatal acuyoga and pregnancy massage to the intensity of low back pain and sleep disturbance of pregnant women trimester III in dr.AisyatulMukminahSp.OG $(K)$ 's own practice in Tulungagung. Types of analytical research associate with one group pre test model - post test design. Independent variable of antenatal acuyoga study and pregnancy massage in third trimester pregnant women, dependent variable of back pain intensity and sleep disturbance of trimester III pregnant women. The study population were All third Trimester pregnant women in dr.AisyatulMukminahSp.OG $(K)^{\prime} s$ own practice in Tulungagung. Sampling technique using simple random sampling with sample of 16 people. Data were analyzed by using Wilcoxon signed rank test, McNemar and Chi Square. The result of the research showed that there was difference of waist pain intensity of trimester III pregnant mother before and after antenatal acuyoga $p=0,005<\alpha(0,05)$. There was no difference of maternal sleep disorder of trimester III before and after performed antenatal acuyoga $(p=0,125>\alpha(0,05)$.There was difference of waist pain intensity of trimester III pregnant mother before and after pregnancy massage ( $p=0,010$ $<\alpha(0,05)$.There is difference of sleep disturbance of pregnant mother of trimester III before and after done pregnancy massage ( $p=0,008<\alpha(0,05)$.
\end{abstract}

Keywords: Acuyoga Antenatal, Pregnancy Massage, Waist Pain, Sleep Disorder.

\section{Background}

Various changes occur in the mother's body during pregnancy. This change aims to accommodate and adapt to the fetus in the womb. These changes include both physical and psychological changes. These changes result in various complaints, disturbances, or discomfort for the mother. More the fetus grows and get older the pregnancy, so more complaints that may be experienced by the mother (Novi, 2010).
Pregnancy is something happy for every couple of husband and wife but sometimes complaints during pregnancy, one of which is very disturbing is the problem of back pain when pregnant. Back pain during pregnancy is usually experienced by women at certain times during pregnancy, usually common in the third trimester of pregnancy. Other problems that occur in the third trimester pregnant women are constipation, respiratory disorders, frequent urination, the 
problem of sleeping in the mother due to infants who often kick at night, varicose veins, swelling and cramps in the legs (Kartikasari, 2016).

The number of pregnancy in Indonesia in 2015 is $87.48 \%$ (Ministry of Health RI, 2016), in East Java province in 2014 as much as $88.66 \%$ (DinkesJatim, 2014) and pregnancy rate in Tulungagung Regency in 2015 as many as $89.71 \%$ (DinkesTulungagung, 2015). From various reports mentioned, about 50$70 \%$ of pregnant women will experience back pain (or pain). While sleep disorders are also often experienced by pregnant women is the decrease in sleep duration (Field et al., 2012). Most pregnant women experience sleep disorders and only $1.9 \%$ of women do not wake up at night during the third trimester of pregnancy. Based on preliminary study in Practice Doctor AisyatulMukminah, $\mathrm{SpOg}$ which we do for 2 days on 6-7 March 2017 got data from 10 pregnant mother of trimester III as much as 2 person (20\%) have low back pain, and 2 person (20\%) experienced sleep disturbance, while 4 people $(40 \%)$ had low back pain and sleep disturbance and 2 people (20\%) were not disturbed.

Acuyoga and massage can ease the complaints of back pain felt by pregnant women because there is a movement that can strengthen the abdominal muscles. Important function of the abdominal muscles is the control of the pelvis when looking up. When the ligaments around the pelvis tighten and no longer provide a strong support to the joints, the muscles become the second line of defense helps prevent excessive stress on the pelvic ligaments. Excessive stress on the pelvis and weakening of the abdominal muscles is what causes low back pain. For that reason, it is necessary to do this exercise to maintain good abdominal muscle tone (Myles, 2010). In addition to doing acuyoga and massage the body will produce more endorphins. Endorphins are known as substances that have a working principle such as morphine that serves to provide calm, overcome stress during pregnancy and able to reduce pain like pain in the waist (Emilia \&Freitag, 2010). Studies show that massage can help solve problems such as anxiety, depression, stress, pain and insomnia by reducing muscle tension (Richards, 2010).

\section{Research Methods}

The research design used True Experimental Design by using model one group pre test - post test design Population in this research is All pregnant mother of trimester III in dr. Aisyatul Mukminah, Sp.OG (K)'s own practice Jl. A. Yani Barat 124 Tulungagung on 1 to 15 September was 28 respondents. The sample of research is determined based on random sampling technique of 16 respondents. Instrument in this research is sheet of quisioner, SOP Acuyoga Antenatal and Pregnancy Massage. The data were analyzed using the signed rank wilcoxon test, mc nemar and chi square.

\section{Results and Discussion \\ Frequency Distribution Based on Waist Pain Before Antenatal Acuyoga}


Distribution of Respondents Based on Waist Pain Before Antenatal Acuyoga in dr. Aisyatul Mukminah, Sp.OG (K)'s own practice in Tulungagung On $16^{\text {th }}$ September Until $16^{\text {th }}$ October , 2017.

\begin{tabular}{|c|c|c|}
\hline Waist pain & $\mathrm{n}$ & $\mathrm{f}(\%)$ \\
\hline $\begin{array}{c}\text { Very hard } \\
\text { pain }\end{array}$ & 0 & 0 \\
\hline Hard pain & 1 & 12.5 \\
\hline Little pain & 7 & 87.5 \\
\hline Mild pain & 0 & 0 \\
\hline Painless & 0 & 0 \\
\hline Total & 8 & 100 \\
\hline
\end{tabular}

Source: primary data of the study

Based on table 4:14 above, showed from 8 respondents most of which are 7 respondents $(87.5 \%)$ waist pain in third trimester pregnant women in the medium category. Lower Waist Pain is a pain that is felt in the lower waist area, may be local pain (inflammation), or radicular pain or both. Pain originating from the lower waist may be referred to other areas, or otherwise pain coming from other regions is felt in the lower pelvic region (referred pain). Lower Waist Pain is essentially a complaint or a symptom and is not a specific disease (Meliala L, 2010).

Pain level is said to be moderate pain if subjectively pregnant mother says moderate pain and objectively client sizzling, grinning, can show location of pain, can describe it, can follow good. Based on the scale of Bourbanis, severe pain includes pain scales of 4 to 6 . If low back pain is not treated immediately, may result in long-term waist pain, increased tendency of postpartum waist pain and chronic waist pain that will be more difficult to treat or cure.

Based on the above facts it is known that there are many factors that affect the first low back pain weight gain. As the weight gain gradually during pregnancy changes the posture so that the center of gravity of the body shifts forward. There is a tendency for the waist muscle to shorten if the abdominal muscles stretch so that it can cause muscle imbalance around the pelvis and additional stress can be felt over the ligament. The result is waist pain that is usually derived from sacroiliac or lumbar, and may become long-term waist disorders if muscle balance and pelvic stability are not restored after delivery. Second, parity, multiparous women who never do exercises whenever they finish giving birth tend to experience abdominal muscle weakness. While primigravida women usually have abdominal muscles are very good because the muscle has never experienced stretch before. Thus, the severity of lower back pain usually increases with the number of parities. This is consistent with the fact that most of the parity of 3rd trimester pregnant women in this study had children 2-4. Increasing parity will cause the lower back pain severity to increase usually. Third, activity, low back pain can also be the result of excessive bending, walking without rest, lifting weights, especially when all these activities are done when the woman is tired (Varney, 2006). The theory is supported by the results of research that most of the trimester 3 pregnant women are housewives 
who daily carry out activities such as sweeping, washing, cooking, and raising children. The housewife's job is so heavy that it causes waist pain in the 3rd trimester.

\section{Frequency Distribution Based on Waist Pain after Acuyoga Antenatal}

Distribution of Respondents Based on Waist Pain After Antenatal Acuyogain dr. Aisyatul Mukminah, Sp.OG (K)'s own practice in Tulungagung On $16^{\text {th }}$ September Until $16^{\text {th }}$ October, 2017.

\begin{tabular}{|c|c|c|}
\hline Waist pain & $\mathrm{n}$ & $\mathrm{f}(\%)$ \\
\hline $\begin{array}{c}\text { Very hard } \\
\text { pain }\end{array}$ & 0 & 0 \\
\hline Hard pain & 0 & 0 \\
\hline Little pain & 0 & 0 \\
\hline Mild pain & 1 & 12.5 \\
\hline Painless & 7 & 87.5 \\
\hline Total & 8 & 100 \\
\hline
\end{tabular}

Source: primary data of the study

Based on table 4:16 above, showed from 8 respondents most of which are 7 respondents (75\%) waist pain in third trimester pregnant women in painless. Acuyoga is a technique of relaxation and massage at a certain point. In acuyoga teaches breathing technique, meditation, body position and massage at certain point. Movements performed such as lotus pose, cobra pose, wind relieving pose, reclined spinal twist and savanna can relax and stretch the cervical muscles of the uterus to smooth the flow of blood and reduce the contractions of the uterus. The acuyoga point that can be used to reduce back pain lies at the kung sun point, san yin ciao point, siehai point and sensen point (Ferry, 2011). In the relaxation techniques acuyoga can stimulate the body to release and increase the production of endorphin substances and enkefalin that serves to inhibit pain. With a little added massage at a certain point will accelerate blood circulation and reduce waist pain in pregnant women third trimester.

In the management of low back pain, aims to reduce lower back pain in third trimester pregnant women so as not to cause great pain. Acuyoga antenatal is one way to reduce back pain during pregnancy. While other ways that Midwives can encourage pregnant women to reduce the pain by maintaining good posture, using the right position when lifting something heavy and not standing for too long.

During the study, of 8 third trimester pregnant women who performed acuyoga antenatal there were 7 respondents who experienced pain reduction became painless. When the mother feels pain, the researcher performs antenatal acuyoga and the pain felt by the mother is reduced. Acuyogaantenatal conducted by researchers have an active influence in reducing the intensity of pain. It can be concluded that, controlling pain and persistent pain is one of the benefits of antenatal acuyoga which can be used as a mild technique of enhancing relaxation by triggering a feeling of comfort through movement and relaxing the muscles and blood flow.

\section{Frequency Distribution Based on Sleep Disorders Before Acuyoga Antenatal}

Distribution of Respondents Based on Sleep Disorders Before 
Acuyoga Antenatal in dr. Aisyatul Mukminah, Sp.OG (K)'s own practice in Tulungagung On $16^{\text {th }}$ September Until $16^{\text {th }}$ October , 2017.

\begin{tabular}{|c|c|c|}
\hline $\begin{array}{c}\text { Sleep } \\
\text { Disorders }\end{array}$ & $\mathrm{n}$ & $\mathrm{f}(\%)$ \\
\hline Abnormal & 8 & 100 \\
\hline Normal & 0 & 0 \\
\hline Total & 8 & 100 \\
\hline
\end{tabular}

Source: primary data of the study

Based on table 4:15 above, showed from 8 respondents all 8 respondents $(100 \%)$ sleep disorders in third trimester pregnant women in abnormal category. According to Bobak (2010) changes in maternal sleep patterns that start during pregnancy especially during the last trimester occur due to physical discomfort and fetal movement that often interfere with mat mother, dyspnea, increased urination, low back pain, constipation, and varicose veins experienced by most women in pregnant the final trimester. Improved abdomen affects the ability to perform daily activities, even a comfortable position is difficult to obtain. In the third trimester the cause of difficulty to fall asleep due to significant physical changes, increased maternal weight resulted in the body feels sore, sleeping position completely wrong. In addition to the discomfort there are several other things that can cause changes in sleep patterns in pregnant women third trimester fetal movements that interfere with the mother's rest, dyspnea, increased urinary, low back pain, constipation and varicose veins (Bobak et al., 2005).
This is in accordance with the circumstances at the time researchers conduct research, where researchers get 8 pregnant women experience sleep disorders. Most pregnant women find it difficult to sleep due to complaints that are felt during third trimester pregnancy . The condition of pregnant women that researchers ask at the time of doing research, that all pregnant women trimester III hamir experienced frequent urination. However, there are two pregnant women who do not experience frequent urination may be influenced because new mothers enter the third trimester and the fetus in the womb is not so large that the pressure made by the presentation of the fetus does not have a big effect on bladder so that mothers do not experience frequent urination.

\section{Frequency Distribution Based on Sleep Disorders after Acuyoga Antenatal}

Distribution of Respondents Based on Sleep Disorders After Antenatal Acuyoga in dr. Aisyatul Mukminah, Sp.OG (K)'s own practice in Tulungagung On $16^{\text {th }}$ September Until $16^{\text {th }}$ October , 2017.

\begin{tabular}{|c|c|c|}
\hline $\begin{array}{c}\text { Sleep } \\
\text { Disorders }\end{array}$ & $\mathrm{n}$ & $\mathrm{f}(\%)$ \\
\hline Abnormal & 4 & 50 \\
\hline Normal & 4 & 50 \\
\hline Total & 8 & 100 \\
\hline
\end{tabular}

Source: primary data of the study Based on table 4:17 above, shows from 8 respondents half of respondents ie 4 respondents $(50 \%)$ sleep disorders third trimester 
pregnant women in the normal category and setenganya again that is 4 respondents $(50 \%)$ sleep disorders third trimester pregnant women in abnormal category. Acuyoga is a technique of relaxation and massage at a certain point. In acuyoga teaches breathing technique, meditation, body position and massage at certain point. Movements performed such as lotus pose, cobra pose, wind relieving pose, reclined spinal twist and savanna can relax and stretch the cervical muscles of the uterus to smooth the flow of blood and reduce the contractions of the uterus. The acuyoga point that can be used to reduce back pain lies at the kung sun point, san yin ciao point, siehai point and sensen point (Ferry, 2011). In the relaxation techniques acuyoga can stimulate the body to release and increase the production of endorphin substances and enkefalin that serves to inhibit pain. With a little added massage at a certain point will accelerate blood circulation and reduce waist pain in third trimester pregnant women.

Provision of acuyoga interverensi in improving the quality of sleep in third trimester pregnant women results obtained that there is less maximal antenatal acuyoga in improving the quality of sleep in pregnant women third trimester where after done antenatal acuyoga still many third trimester pregnant women who suffered from sleep disorders.

\section{Frequency Distribution Based on Waist Pain Before Pregnancy Massage}

Distribution of Respondents

Based on Waist Pain Before
Pregnancy Massage at dr. Aisyatul Mukminah, Sp.OG (K)'s own practice in Tulungagung On $16^{\text {th }}$ September Until $16^{\text {th }}$ October , 2017.

\begin{tabular}{|c|c|c|}
\hline Waist pain & $\mathrm{n}$ & $\mathrm{f}(\%)$ \\
\hline Very hard pain & 0 & 0 \\
\hline Hard pain & 2 & 25 \\
\hline Little pain & 6 & 75 \\
\hline Mild pain & 0 & 0 \\
\hline Painless & 0 & 0 \\
\hline Total & 8 & 100 \\
\hline
\end{tabular}

Source: primary data of the study

Based on table 4:18 above, showed from 8 respondents most of which are 6 respondents (75\%) waist pain in third trimester pregnant women in the medium category. Lower Waist Pain is a pain that is felt in the lower waist area, may be local pain (inflammation), or radicular pain or both. Pain originating from the lower waist may be referred to other areas, or otherwise pain coming from other regions is felt in the lower pelvic region (referred pain). Lower Waist Pain is essentially a complaint or a symptom and is not a specific disease (Meliala L, 2010).

Pain level is said to be moderate pain if subjectively pregnant mother says moderate pain and objectively client sizzling, grinning, can show location of pain, can describe it, can follow good. Based on the scale of Bourbanis, severe pain includes pain scales of 4 to 6. If low back pain is not treated immediately, may result in long-term waist pain, increased tendency of postpartum waist pain and chronic waist pain that will be more difficult to treat or cure. 
Based on the above facts it is known that there are many factors that affect the first low back pain weight gain. As the weight gain gradually during pregnancy changes the posture so that the center of gravity of the body shifts forward. There is a tendency for the waist muscle to shorten if the abdominal muscles stretch so that it can cause muscle imbalance around the pelvis and additional stress can be felt over the ligament. The result is waist pain that is usually derived from sacroiliac or lumbar, and may become long-term waist disorders if muscle balance and pelvic stability are not restored after delivery. Second, parity, multiparous women who never do exercises whenever they finish giving birth tend to experience abdominal muscle weakness. While primigravida women usually have abdominal muscles are very good because the muscle has never experienced stretch before. Thus, the severity of lower back pain usually increases with the number of parities. This is consistent with the fact that most of the parity of 3rd trimester pregnant women in this study had children 2-4. Increasing parity will cause the lower back pain severity to increase usually. Third, activity, low back pain can also be the result of excessive bending, walking without rest, lifting weights, especially when all these activities are done when the woman is tired (Varney, 2006). The theory is supported by the results of research that most of the third trimester pregnant women are housewives who daily carry out activities such as sweeping, washing, cooking, and raising children. The housewife's work is so heavy that it causes low back pain in the third trimester.

\section{Frequency Distribution Based on Waist Pain after Pregnancy Massage}

Distribution of Respondents Based on Waist Pain After Pregnancy Massage at dr. Aisyatul Mukminah, Sp.OG (K)'s own practice in Tulungagung On $16^{\text {th }}$ September Until $16^{\text {th }}$ October , 2017.

\begin{tabular}{|c|c|c|}
\hline Waist pain & $\mathrm{n}$ & $\mathrm{f}(\%)$ \\
\hline Very hard pain & 0 & 0 \\
\hline Hard pain & 0 & 0 \\
\hline Little pain & 0 & 0 \\
\hline Mild pain & 6 & 75 \\
\hline Painless & 2 & 25 \\
\hline Total & 8 & 100 \\
\hline
\end{tabular}

Source: primary data of the study

Based on table 4:20 above, showed from 8 respondents most of which are 6 respondents (75\%) waist pain in third trimester pregnancy women in the category of light.

Massage is the application of pressure on the soft tissues of the body, such as skin, muscles, tendons and ligaments. Massage or massage is one way to bring up wellness for body and mind. Massage is as a massage that has been perfected with the sciences of the human body or mechanical hand movements of the human body using a variety of forms of grip or technique (IHCA, 2014).

In the management of low back pain, aims to reduce lower back pain in third trimester pregnant women so as not to cause great pain. Pregnancy massage is one way to reduce back pain during pregnancy. 
While other ways that Midwives can encourage pregnant women to reduce the pain by maintaining good posture, using the right position when lifting something heavy and not standing for too long.

During the study, of 8 in third trimester pregnant women conducted pregnancy massage there were 6 respondents who experienced a decrease in pain from moderate pain into mild pain. When the mother feels pain, the researcher performs the pregnancy massage and the pain felt by the mother is reduced. Pregnancy massage conducted by researchers has an active influence in reducing the intensity of pain. It can be concluded that, controlling the pain and persistent pain is one of the benefits of pregnancy massage which can be used as a mild technique to increase relaxation by triggering a feeling of comfort because the muscles become sagging and blood flow smoothly.

\section{Frequency Distribution Based on Sleep Disorders Before Pregnancy Massage}

Distribution of Respondents Based on Sleep Disorders Before Pregnancy Massage at dr. Aisyatul Mukminah, Sp.OG (K)'s own practice in Tulungagung On $16^{\text {th }}$ September Until $16^{\text {th }}$ October , 2017.

\begin{tabular}{|c|c|c|}
\hline $\begin{array}{c}\text { Sleep } \\
\text { Disorders }\end{array}$ & $\mathrm{n}$ & $\mathrm{f}(\%)$ \\
\hline Abnormal & 8 & 100 \\
\hline Normal & 0 & 0 \\
\hline Total & 8 & 100 \\
\hline
\end{tabular}

Source: primary data of the study

Based on table 4:19 above, showed from 8 respondents all 8 respondents (100\%) sleep disorders third trimester pregnant women in abnormal category.

According to Bobak (2010) changes in maternal sleep patterns that start during pregnancy especially during the last trimester occur due to physical discomfort and fetal movement that often interfere with mat mother, dyspnea, increased urination, low back pain, constipation, and varicose veins experienced by most women in pregnant the final trimester. Improved abdomen affects the ability to perform daily activities, even a comfortable position is difficult to obtain. In the third trimester the cause of difficulty to fall asleep due to significant physical changes, increased maternal weight resulted in the body feels sore, sleeping position completely wrong. In addition to the discomfort there are several other things that can cause changes in sleep patterns in pregnant women third trimester fetal movements that interfere with the mother's rest, dyspnea, increased urinary, low back pain, constipation and varicose veins (Bobak et al., 2005).

This is in accordance with the circumstances at the time researchers conduct research, where researchers get 8 pregnant women experience sleep disorders. Most pregnant women find it difficult to sleep due to complaints that are felt during trimester pregnancy. The condition of pregnant women that researchers ask at the time of doing research, that almost all third trimester pregnant women experienced frequent urination. However, there are two pregnant women who do not experience frequent urination may be 
influenced because new mothers enter the third trimester and the fetus in the womb is not so large that the pressure made by the presentation of the fetus does not have a big effect on bladder so that mothers do not experience frequent urination.

\section{Frequency Distribution Based on Sleep Disorders after Pregnancy Massage}

Distribution of Respondents Based on Sleep Disorders After Pregnancy Massage at dr. Aisyatul MukminahSp.OG (K)'s own practice in Tulungagung On $16^{\text {th }}$ September Until $16^{\text {th }}$ October, 2017.

\begin{tabular}{|c|c|c|}
\hline $\begin{array}{c}\text { Sleep } \\
\text { Disorders }\end{array}$ & $\mathrm{n}$ & $\mathrm{f}(\%)$ \\
\hline abnormal & 0 & 0 \\
\hline Normal & 8 & 100 \\
\hline Total & 8 & 100 \\
\hline
\end{tabular}

Source: primary data of the studyBased on table 4:21 above, showed from 8 respondents all 8 respondents $(100 \%)$ sleep disorders third trimester pregnant women in the normal category. Massage is the application of pressure on the soft tissues of the body, such as skin, muscles, tendons and ligaments. Massage or massage is one way to bring up wellness for body and mind. Massage is as a massage that has been perfected with the sciences of the human body or mechanical hand movements of the human body using a variety of forms of grip or technique (IHCA, 2014).Giving interverensi pregnancy massage in improving sleep quality in third trimester pregnant woman got result that there is improvement of quality at third trimester pregnant woman where in its implementation use measurement with questionnaire of sleep disorder.

\section{Bivariate Statistics Test Results} Table 4.42 Bivariate Statistics Test Results

\begin{tabular}{|c|c|c|}
\hline Variabel & Analisis & $\mathrm{P}$ \\
\hline $\begin{array}{c}\text { Waist pain } \\
\text { before*afterAcuyoga } \\
\text { Antenatal }\end{array}$ & $\begin{array}{l}\text { Wilcoxon } \\
\text { Signed } \\
\text { Rank }\end{array}$ & 0.005 \\
\hline $\begin{array}{l}\text { Waist pain before*after } \\
\text { Pregnancy } \\
\text { Massage }\end{array}$ & $\begin{array}{l}\text { Wilcoxon } \\
\text { Signed } \\
\text { Rank }\end{array}$ & 0.010 \\
\hline $\begin{array}{c}\text { Sleep disorders } \\
\text { before*after } \\
\text { Acuyoga Antenatal }\end{array}$ & $\begin{array}{c}\text { McNemar } \\
\text { Test }\end{array}$ & 0.125 \\
\hline $\begin{array}{c}\text { Sleep disorders } \\
\text { before*after } \\
\text { Pregnancy Massage }\end{array}$ & $\begin{array}{c}\text { McNemar } \\
\text { Test }\end{array}$ & 0.008 \\
\hline $\begin{array}{l}\text { Waist pain } \\
\text { beforeAcuyoga* } \\
\text { Waist pain } \\
\text { beforeAcuyoga } \\
\text { Antenatal }\end{array}$ & $\begin{array}{c}\text { Chi } \\
\text { Square }\end{array}$ & 0.537 \\
\hline $\begin{array}{l}\text { Waist pain after } \\
\text { Acuyoga* } \\
\text { Waist pain after } \\
\text { Pregnancy } \\
\text { Massage }\end{array}$ & $\begin{array}{c}\text { Chi } \\
\text { Square }\end{array}$ & 0.537 \\
\hline $\begin{array}{c}\text { Sleep disorders before } \\
\text { Acuyoga* Sleep } \\
\text { disorders } \\
\text { beforeAcuyoga } \\
\text { Antenatal }\end{array}$ & $\begin{array}{c}\text { Chi } \\
\text { Square }\end{array}$ & - \\
\hline $\begin{array}{l}\text { Sleep disorders after } \\
\text { Acuyoga* } \\
\text { Sleep disorders after } \\
\text { Pregnancy } \\
\text { Massage }\end{array}$ & $\begin{array}{c}\text { Chi } \\
\text { Square }\end{array}$ & - \\
\hline
\end{tabular}

Source: primary data of the study

Based on table 4:42 shows the test results wilcoxon signed rank between waist pain before with after antenatal acuyoga obtained $\mathrm{p}=0.005$ where $\mathrm{p}<\alpha(0.05)$ so that $\mathrm{H} 0$ rejected which means that there is difference in intensity of abdominal pain of third trimester pregnant women before and after done acuyoga 
antenatal in dr.Aisyatul Mukminah Sp.OG (K)'s practice in Jl. A. Yani Barat 124 Tulungagung.

Based on table 4:42 shows the test results wilcoxon signed rank between waist pain before with after pregnancy massage obtained $\mathrm{p}=$ 0.010 where $\mathrm{p}<\alpha(0.05)$ so that $\mathrm{H} 0$ rejected which means that there is difference in intensity of waist pain of third trimester pregnant mother before and after done pregnancy massage in dr.Aisyatul Mukminah Sp.OG (K)'s practice in J1. A. Yani Barat 124 Tulungagung.

Based on Table 4:42 shows the results of McNemar test between Sleep Disorders before with after antenatal Acuyoga obtained $\mathrm{p}=$ 0.125 where $p>\alpha(0.05)$ so that $\mathrm{H} 0$ is accepted which means that there is no difference in intensity of sleep disturbance of third trimester pregnant women before and after done acuyoga antenatal in dr.Aisyatul Mukminah Sp.OG (K)'s practice in Jl. A. Yani Barat 124 Tulungagung.

Based on Table 4:42 shows the results of McNemar test between sleep disorders before with after pregnancy massage obtained $\mathrm{p}=$ 0.008 where $\mathrm{p}<\alpha(0.05)$ so that $\mathrm{H} 0$ rejected which means that there are differences in sleep disturbance of third trimester pregnant women before and after pregnancy massage done in dr.Aisyatul Mukminah Sp.OG (K)'s practice in Jl. A. Yani Barat 124 Tulungagung.

Based on Table 4:42 shows Chi Square test results between waist pain after acuyoga antenatal with after pregnancy massage obtained $\mathrm{p}$ $=0.537$ where $\mathrm{p}>\alpha(0.05)$ means there is no relationship between waist pain after acuyoga antenatal with after pregnancy massage in dr.Aisyatul Mukminah Sp.OG (K)'s practice in Jl. A. Yani Barat 124 Tulungagung.

Based on Table 4:42 shows Chi Square test results between sleep disturbances after acuyoga antenatal with after pregnancy massage obtained $\mathrm{p}=$ - because there is a mulak value in sleep disturbance variables.

\section{Conclusions}

1. Intensity of waist pain before acuyoga antenatal in third trimester pregnant mother in dr.Aisyatul Mukminah Sp.OG $(\mathrm{K})$ 's practice in Jl. A. Yani Barat 124 Tulungagung most of which are 7 respondents $(87.5 \%)$ waist pain of third trimester pregnant women in medium category

2. Intensity of waist pain after Acuyoga Antenatal on third trimester pregnant women in dr.Aisyatul Mukminah Sp.OG (K)'s practice in Jl. A. Yani Barat 124 Tulungagung most of which are 7 respondents $(75 \%)$ waist pain in third trimester pregnant women in no pain

3. Sleep disturbance before antenatal acuyoga in pregnant mother of third trimester in dr.Aisyatul Mukminah Sp.OG (K)'s practice in Jl. A. Yani Barat 124 Tulungagung entirely 8 respondents $(100 \%)$ sleep disorders of third trimester pregnant women in abnormal category

4. Sleep disturbance after Acuyoga Antenatal in third trimester pregnant mother in dr.Aisyatul Mukminah Sp.OG (K)'s practice 
in Jl. A. Yani Barat 124 Tulungagung half of respondents ie 4 respondents $(50 \%)$ sleep disorder of third trimester pregnant woman in normal category and the same again that is 4 respondent $(50 \%)$ sleep disorder of third trimester pregnant woman in abnormal category

5. Intensity of waist pain before Pregnancy Massage in third trimester pregnant women indr. Aisyatul Mukminah Sp.OG (K)'s practice in J1. A. Yani Barat 124 Tulungagung most of which are 6 respondents $(75 \%)$ waist pain of third trimester pregnant women in medium category

6. Intensity of waist pain after pregnancy massage in third trimester pregnant women in dr.Aisyatul Mukminah Sp.OG (K)'s practice in Jl. A. Yani Barat 124 Tulungagung most of which are 6 respondents (75\%) low back pain of third trimester pregnant women in the mild category

7. Sleep disturbance before Pregnancy Massage in pregnant mother of third trimester in dr.Aisyatul Mukminah Sp.OG (K)'s practice in Jl. A. Yani Barat 124 Tulungagung entirely 8 respondents (100\%) sleep disorders of third trimester pregnant women in abnormal category

8. Sleep disturbance after pregnancy massage in third trimester pregnant women in dr.Aisyatul Mukminah Sp.OG (K)'s practice in Jl. A. Yani Barat 124 Tulungagung entirely 8 respondents (100\%) sleep disorders of third trimester pregnant women in normal category

9. There is difference in intensity of waistline of third trimester pregnant mother before and after done antenatal acuyoga in dr.Aisyatul Mukminah Sp.OG $(\mathrm{K})$ 's practice in Jl. A. Yani Barat 124 Tulungagung $(\mathrm{p}=0.005<\alpha$ (0.05).

10. There is no difference in sleep disturbance of third trimester pregnant women before and after performed acuyoga antenatal in dr.Aisyatul Mukminah Sp.OG (K)'s practice in Jl. A. Yani Barat 124 Tulungagung $(\mathrm{p}=0.125>\alpha$ (0.05).

11. There is difference of intensity of waistline of pregnant mother of third trimester before and after done pregnancy massage in dr.Aisyatul Mukminah Sp.OG $(\mathrm{K})$ 's practice in Jl. A. Yani Barat 124 Tulungagung $(\mathrm{p}=0.010<\alpha$ (0.05) .

12. There is difference of sleep disturbance of pregnant mother of third trimester before and after done pregnancy massage in dr.Aisyatul Mukminah Sp.OG $(\mathrm{K})$ 's practice in Jl. A. Yani Barat 124 Tulungagung $(\mathrm{p}=0.008<\alpha$ (0.05) .

13. There is no difference of waistline pain of pregnant mother of third trimester after done antenatal acuyoga and after done pregnancy massage in dr.Aisyatul Mukminah Sp.OG (K)'s practice in Jl. A. Yani Barat 124 Tulungagung $(\mathrm{p}=0,537>\alpha$ (0.05).

14. Differences of sleep disturbance of pregnant mother of 
third trimester after done antenatal acuyoga and after done pregnancy massage in dr.Aisyatul Mukminah Sp.OG (K)'s practice in Jl. A. Yani Barat 124 Tulungagungcan not be analyzed.

\section{Suggestions}

1. For Researchers

This research is expected to increase the insight, knowledge and experience of the researcher and also apply the theory about the influence of antenatal acuyoga and pregnancy massage to decrease the intensity of waist pain and sleep disorder of third trimester pregnant woman .

2. Divide the Land

The health authorities are expected to provide additional discourse about the complaints experienced during the $3 \mathrm{rd}$ trimester pregnancy so that the 3rd trimester pregnant women can find an alternative to reduce the complaint by following acuyoga antenatal and pregnancy massage.

3. For Educational Institutions

This research is expected to add treasury treasury research, especially in STIKes Surya Mitra Kediri. And can be a reference for further studies on the influence of antenatal acuyoga and pregnancy massage to decrease the intensity of low back pain and sleep disorders of third trimester pregnant women

4. For Further Researchers

It is expected to conduct further research related to the influence of antenatal acuyoga and pregnancy massage to decrease the intensity of waist pain and sleep disorders of third trimester pregnant women.

\section{REFERENCE}

Arikunto, S. 2013. Prosedur Penelitian Suatu Pendekatan Proses. Jakarta: Rineka Cipta.

Brayshaw, Ellen. 2010. Senam Hamil dan Nifas. Jakarta: EGC.

Craven, R. F., \& Hirnle, C. J., 2010.Rencana Pembangunan Kesehatan Menuju Indonesia Sehat. Penerbit Depkes RI.

DinkesKab. Tulungagung.(2015). Profil Kesehatan Kabupaten Tulungagung 2014. Tulungagung : Dinas Kesehatan Tulungagung.

Ehrlich GE. 2010. Low back pain. Bulletin of the World Health Organization; Internasional Journal of Health 81(9): 671676.

Emilia, O \&Freitag, H. 2010. Tetap bugar dan energik selama hamil. Jakarta:

Fraser, Diane M.2009.Buku Ajar Bidan Myles. Jakarta : EGC.

Guyton, A.C., \& Hall, J.E.. 2010. Fisiologi Kedokteran, edisi ke $12 . \quad$ Penerjemah: Widjajakusuma $\mathrm{MH}$ dan Tanzil A. Jakarta: Saunders Elseveie.

Hidayat, Alimul Aziz. 2011. Metode Penelitian Kebidanan teknik analisa data. Jakarta: Salemba Medika.

IHCA. 2014. Pregnancy Massage and Acuyoga Antenatal. Jakarta: Indonesian Holistic Care Association. 
Indrayani. 2011. Buku Ajar Asuhan Kehamilan. Jakarta: CV. Trans Info Media.

Manuaba, IBG, dkk. 2010. Ilmu Kebidanan Penyakit Kandungan Dan KB. Jakarta: EGC.

Medforth, Janet, dkk. 2011. Kebidanan Oxford. Jakarta : EGC.

Meliala L, 2010. Nyeri Punggung Bawah, Kelompok Studi Nyeri Perhimpunan Dokter Spesialis Saraf Indonesia. Jakarta

Mochtar R.1998. Sinopsis Opstetri Fisiologi \& Patologi. Jakarta: EGC.

Nursalam. 2008. Konsepdan Penerapan Metodologi Penelitian Ilmu Keperawatan, Pedoman Skripsi, Tesis, dan Instrumen Penelitian. Jakarta: Salemba Medika.

Picavet HSJ, Vlaeyen JWS, Schouten JSAG. 2002. Pain catastrophizing

andkinesiophobia: predictors of chronic low back pain. Am JournalEpidemiologi; 156: 1028-1034.

Potter dan Perry. 2010. Buku Ajar Fundamental Keperawatan :Konsep,Proses,danPraktik Vol. 1. Jakarta : EGC.

Pravikasari, Nila Analisa et al. 2014. Perbedaan Senam Hamil dan Teknik Akupresur Terhadap Penurunan Nyeri Punggung Bawah pada Ibu Hamil Trimester III. Thesis. Semarang: Program
Pascasarjan Universitas Diponegoro

Prawirohardjo, S. 2009. Ilmu Kebidanan. Jakarta: Yayasan Bina Pustaka Sarwono Prawirohardjo.

Saifudin, AB. (2009). Buku Acuan Pelayanan Kesehatan Maternal dan Neonatal. Jakarta: PT. Bina Pustaka Sarwono Prawirohardjo.

Saminem, Hajjah. (2009). Kehamilan Normal. Jakarta : EGC

Simkin, Penny. 2010. Panduan Lengkap Kehamilan, Melahirkan dan Bayi, Jakarta: ARCAN.

Sugiyono.2010. Metode Penelitian Kunatitatif Kualitatif dan $R \& D$. Bandung.Alfabeta.

Varney, Helen, dkk. (2010). Buku Ajar Asuhan Kebidanan Edisi 4 Volume 1. Jakarta: Penerbit Buku Kedokteran EGC.

Wong, Ferry. (2011). ACUYOGA Kombinasi Acupresure dan Yoga. Jakarta. Penebar Plus. 